\title{
An Assessment of the Effects of ENSO Events on Fresh Vegetable and Melon Supplies
}

\author{
Jaehong Park ${ }^{1}$ \\ Department of Agricultural Economics, Kyungpook National University, \\ Korea
}

James W. Mjelde ${ }^{2}$, Stephen W. Fuller ${ }^{2}$, Jaime E. Malaga ${ }^{3}$, and
C. Parr Rosson ${ }^{2}$
Department of Agricultural Economics, Texas A\&M University, College
Station, TX $77843-2124$

Frank J. Dainello

Department of Horticultural Sciences, Texas A\&M University, College Station, TX 77843

Additional index words. El Niño, La Niña, ENSO, vegetables, melons

\begin{abstract}
The historical effects of El Niño/La Niña events on supplies of selected fresh vegetables and melons (Cucumis melo $\mathrm{L}$.) were evaluated by estimating single-equation supply relationships. Economic variables in the estimated equations were, generally, of the correct sign and significant at usual levels. EI Niño events had a negative and statistically significant effect on the Texas muskmelon, Florida fall squash [Praecitrullus fistulosus Stocks) Pang.] and the California fall lettuce (Lactuca sativa L.) supply with expected production declines of $15 \%, 21 \%$, and $5 \%$ relative to historical mean production. In contrast, the expected supplies of United States summer onions (Allium cepa L.) and Florida fall and winter tomatoes (Lycopersicon esculentum Mill.) increased about 7\%, $10 \%$, and $25 \%$ during EI Niño events. La Niña events had a negative and significant effect on Texas muskmelon, honeydew, and watermelon, with supplies expected to decline $20 \%$, $29 \%$, and $13 \%$ with the occurrence of this event.
\end{abstract}

Given the events of recent years, especially the media attention, almost everyone is aware of the El Niño/La Niña phenomena and their potential impacts on society. Many of the impacts discussed in the media have little scientific basis. Single weather events, for example, have been attributed to these phenomena. Currently, it is neither possible nor correct to attribute a single weather event to the El Niño/La Niña phenomena. Strong weather events occur every year. What can be attributed to these phenomena are longer term climate events (period of two weeks or longer). The development of an El Niño or La Niña event does not insure the expected climate impact will occur. A region whose expected winter climate is, for example, drier than normal during El Niño events may, during a particular event experience wetter than normal conditions.

Received for publication: 25 Aug. 2000. Accepted for publication: 25 June 2001. This research was funded by the Dept. of Commerce, National Oceanic and Atmospheric Administration Grant No. NA66GP0189, the Texas Agricultural Extension Service, the Texas Agricultural Experiment Station, and the Center for North American Studies.

${ }^{1}$ Post Doctoral Research Associate.

${ }^{2}$ Professor.

${ }^{3}$ Assistant Professor. Current address: Dept. of Agricultural and Applied Economics, Texas Tech Univ., Lubbock, TX 79409-2132.
Two interrelated components, Pacific sea surface temperature anomalies, El Niño (EN), and sea surface air pressure/wind fluctuations, the Southern Oscillation (SO), comprise the ENSO phenomenon. In recent literature, the term ENSO refers to El Niño and La Niña events. Under "normal" conditions, a warm pool of water in the tropical western Pacific extends to a depth of 100-200 m. In the eastern Pacific, warmer sea surface waters are displaced by westward flowing winds, causing cooler subsurface water to rise and fill the void. The winds and subsequent upwelling result in a cold tongue of water extending along the equator from Peru to the mid-Pacific (Glantz, 1996). This warm pool in the western Pacific is a major source of atmospheric heating and formation of rain clouds. The airflow process is completed by an eastward wind flow at high altitudes from the western Pacific that descends over the eastern Pacific. This airflow pattern is known as the Walker Circulation.

During an El Niño event, the Walker Circulation weakens, reducing the upwelling of colder subsurface waters in the eastern $\mathrm{Pa}$ cific. Consequently, the thermocline deepens in the east, creating a warm pool of water in the eastern Pacific similar to that found in the western Pacific. Simultaneously, the decline in winds reduces the amount of warm water being forced to the western Pacific causing the thermocline to become shallower in the west (Wyrki et al., 1976). Shifts in the warm pool impact atmospheric heating, which, in turn, shifts the location of rain cloud formation and air circulation.

Water in the eastern Pacific becomes relatively colder than normal during a La Niña event. The wind patterns normally observed become more intense because of the greater relative difference in air pressure across the equatorial Pacific. In areas impacted by ENSO, climatic anomalies tend to be the opposite of those observed during El Niño events (Kiladis and Diaz, 1989; Ropelewski and Halpert, 1986, 1987, 1989).

Shifts in the Walker Circulation modify air flows north and south of the equator via the Hadley Circulation. These shifts affect the jet stream which modifies storm patterns in North America and elsewhere (Glantz, 1996; Hammer et al., 1996; Kiladis and Diaz, 1989; Ropelewski and Halpert, 1986, 1987, 1989). Based on Green et al. (1997), Ropelewski and Halpert (1986, 1987, 1989), and the National Oceanic and Atmospheric Administration (NOAA) (1998), composite generalities of winter precipitation and temperature can be generated. El Niño events are correlated with increased fall through spring precipitation in the Gulf Coast and southwest. During the same time period, El Niño events are correlated with decreased precipitation in the northwest and northeast. In the Mexican Pacific and Gulf coast regions, winter precipitation is also positively correlated with El Niño events. Although an opposite pattern of precipitation is found for La Niña events, the correlation with Mexican precipitation appears to be weak. Temperature anomalies also appear to be correlated with ENSO events, but the correlations do not appear to be as strong or as widespread. Warmer temperatures are associated with the drier weather, whereas areas associated with wetter weather also experience cooler temperatures.

This study evaluated the historical effects of El Niño/La Niña events on the supplies of selected fresh vegetables and melons (Cucumis melo L.). To our knowledge, no scientific research has been published on the effects of El Niño/La Niña events on vegetable crops, however, several studies have shown mixed impacts of these events on field crops (Cane et al., 1994; Mjelde and Keplinger, 1998; Nicholls, 1988). For this study, 17 vegetable and melon supply relationships that include El Niño/La Niña events were estimated. Supply relationships were estimated for: United States spring and summer onions (Allium cepa L.); Mexican muskmelon and watermelon; Texas spring onion, summer onion, muskmelon, honeydew, and watermelon; Florida fall squash [Praecitrullus fistulosus Stocks) Pang.], winter squash, fall green pepper (capsicum annuum L.), winter green pepper, fall tomato (Lycopersicon esculentum Mill.) and winter tomato; and California fall and winter lettuce (Lactuca sativa L.).

\section{Materials and Methods}

To examine the effect of El Niño/La Niña events on vegetable and melon production, 
supply equations were estimated for selected crops produced in the United States and Mexico. Ordinary least squares was used to estimate supply equations of the general form:

$$
S_{t}=f\left(S_{t-1}, P_{t-1}, W_{t}, \text { El Niño }, \text { La Niña }{ }_{t}\right)
$$

where $S_{t}=$ supply in season $t, P_{t-1}=$ price in the previous season, $\mathrm{W}_{\mathrm{t}}=$ wage rate, and $\mathrm{El}$ Niño and La Niña events are represented as binary variables.

Because the objective was to isolate the effects of El Niño/La Niña events on total supply, simple single equation supply functions were estimated instead of two separate equations representing yield and harvested acreage. Supply in period $t$ was assumed to be related to supply in period $\mathrm{t}-1$ because of resource fixity, managerial constraints, contractual obligations, and production habits. Tomek and Robinson (1981) note lagged supply is correlated with the influence of technology. Consequently, no proxy variables for technology were included in the specified model. Lagged supply was expected to have a positive affect on current supply. The lagged price variable serves as a proxy for farmer price expectations and was expected to have a positive influence on current supply. The wage rate serves as a proxy for vegetable and melon production costs and was thought to have a negative affect on current supply. There were no a priori expectations regarding the signs on the El Niño and La Niña binary variables.

Data. Data to estimate the supply relationships came from various sources. Because of the unavailability of selected commodity data, the number of observations varies between the estimated relationships. United States spring and summer onion price and production data extend from 1964 through 1996 [U.S. Dept. of Agriculture (USDA), Agricultural Statistics, 1961-96]. Texas onion and melon price and production data extend from 1961 through 1996 (Texas Dept. of Agriculture, 1971-96). Texas spring onions are planted in the fall and harvested in midMarch through June, while melons are planted in the winter and early spring (January through April) and harvested in mid-spring and summer (May through September). Spring onion production is located in south Texas (Winter Garden, lower Rio Grande Valley and Laredo area) as is muskmelon and honeydew production. Texas watermelon production is concentrated in the San Antonio/Wintergarden area (20\%), Coastal Bend (19\%), central Texas (15\%), east Texas (15\%), lower Rio Grande Valley (10\%), north Texas (8\%), and High Plains $(6 \%)$. Data for muskmelon and watermelon were unavailable for 1988 and 1989.

Production and price data for the 1968 through 1996 period were used to estimate the Florida supply relationships (Florida Dept. of Agriculture and Consumer Service, 1968-96). Planting of fall-harvested green pepper commences in early August with subsequent harvest starting in the last-half of October. About $25 \%$ of Florida green pepper production is in the fall season. Planting of the winter green pepper production commences in mid-October and comprises $\approx 33 \%$ of the Florida annual green pepper output. Florida green pepper production is concentrated in the southwest (43\%), southeast (33\%), and westcentral (14\%) regions. Planting of Florida fall-harvested tomatoes commences in late July with the subsequent harvest commencing in mid-October. Winter tomato planting commences in October. The fall and winter season production each comprise $\approx 33 \%$ of the annual Florida tomato output. About $70 \%$ of Florida tomato production is located in the west central ( $\mathrm{Pal}-$ metto-Ruskin area) and southwest regions. Remaining production is located in Dade County, the southeast coastal area, and north and west Florida. Florida squash production is concentrated in the southeast $(30 \%)$, southwest $(15 \%)$, north central $(10 \%)$, west central $(10 \%)$, and north $(8 \%)$ regions. About $66 \%$ of the annual squash production takes place in the fall and winter seasons with nearly equal quantities produced in each season. Planting of fall-harvested squash starts in August, while planting of winter-harvested squash commences in October.

Because California lettuce production data were not available by season, monthly shipment data were aggregated into fall and winter shipments to serve as a proxy for production (USDA, Fresh Fruit and Vegetable Shipments: By Commodities, States and Months 197196). California monthly lettuce price data came from USDA's Agricultural Prices (1971-96). Supply relationships were based on data from 1971 through 1996. Fall lettuce production in California is concentrated in central California and the Imperial Valley, while winter production is concentrated in the Imperial Valley and southern California.

Vegetable and melon production is labor intensive, therefore, a wage rate index was used as a proxy for production cost in the U.S. supply equations (USDA, Agricultural Statistics 1961-96). Vegetable and melon price data and the wage rates for U.S. production were deflated using the Consumer Price Index (U.S. Government Printing Office 1996).

Mexican melon production and price data, from 1970 through 1994, came from Anuarios Estadisticos de la Produccion Agricola de Los Estados Unidos Mexicanos (Secretaria de Agricultura y Recursos hidraulicos, 197094). Mexican muskmelon production is concentrated in the states of Michoacan, Sinaloa, Colima, Guerrero, Nayarit, Jalisco, and Tamaulipas. All states border the Pacific Ocean except Michoacan, which is in west central Mexico, and Tamaulipas, which borders south Texas and the Gulf of Mexico. Mexican watermelon production is located in Sinaloa, Jalisco, Sonora, Veracruz, Tabasco, and Tamaulipas. All states are located in west Mexico except Tamaulipas, Tabasco, and Veracruz, which border the Gulf of Mexico. About $85 \%$ of Mexico's melon production in the fall and winter season is produced in these states with most production destined for the U.S. market. The labor cost index for Mexico came from the Comisión Nacional de los Salarios Minimos (1997). Prices (in pesos) and labor costs were deflated by a wholesale price index from the Banco de Mexico (1970-94).

Classification of ENSO events was from NOAA (2001). Years classified as either moderate or strong in intensity were used to classify ENSO events in this study. ENSO events as defined by the above criteria eliminate the weak events. If moderate to strong events does not lead to expected supply changes, it is believed the weak ENSO events would also not affect supply. Over the 1961-96 period, the years $1965,1968-69,1972,1982,1987$, 1990-92, and 1994 were classified as El Niño years. La Niña years were 1964, 1970, 1973, 1974, 1975, and 1988. For purposes of this study, years were defined on an October-toOctober basis, because ENSO events' main influence is during the October to March/ April period and the fall and winter agricultural production periods used. To clarify, consider 1970, a La Niña year. This event affected Fall 1970 production (October, November, and December) and winter and spring production in 1971. Such adjustments were made when estimating the equations. Descriptive statistics for the variables used in estimating the different supply relationships are presented in Table 1.

\section{Results and Discussion}

The parameters of the supply equations were estimated using three alternative functional forms (linear, log-log, and semi-log). Only the linear form (Table 2) is presented for the 17 supply equations because the inferences from the other forms were similar. The adjusted $R^{2}$, s ranged from 0.10 for Texas spring onions to 0.89 for California winter lettuce. Based on the Runs test (the Runs test is a nonparametric test that is designed to determine if the residuals are purely random), serial correlation was not evident except for the Texas honeydew melon equation (Gujarati). Thus, some caution is warranted when inferring the statistical significance of estimated coefficients in this equation, although new studies suggest serial correlation has little bearing on the robustness of $t$ and $\mathrm{F}$ tests (Banerjee and Magnus, 2000). The economic variables included in the estimated equations tend to have the expected signs. For all except one equation, the coefficients on the lagged supply variables were positive as expected and significant at the $0.05 \%$ or $0.10 \%$ levels. The signs on the lagged price variables were positive as anticipated in 12 equations and significant at the 0.20 or less level in seven of these 12 equations. The estimated signs on the wage rate variables were negative as expected in 11 of the 17 equations and significant at the 0.20 or less level in two of these equations. Unexpectedly, coefficients associated with wage rates are positive and significant in two equations, however, in no other estimated equation was a variable with an unanticipated sign found to be significant at usual levels. Real wage rates during the study period varied little, hence, a possible reason for the modest explanation offered by this variable (Table 1). 
Table 1. Descriptive statistics of the variables used to estimate supply relationships. ${ }^{\mathrm{z}}$

\begin{tabular}{|c|c|c|c|c|c|}
\hline Description & Mean & SD & Minimum & Maximum & Obs. \\
\hline \multicolumn{6}{|c|}{ United States } \\
\hline Summer onion production & 3605.9 & 916.77 & 2333.0 & 6239.0 & 32 \\
\hline Spring onion production & 6620.7 & 1482.6 & 3589.0 & 10297.0 & 32 \\
\hline Summer onion price & 9.85 & 4.21 & 3.15 & 17.80 & 32 \\
\hline Spring onion price & 13.65 & 4.98 & 7.83 & 30.63 & 32 \\
\hline \multicolumn{6}{|c|}{ Mexico } \\
\hline Winter watermelon production & 193660.0 & 62539. & 99950. & 298120. & 24 \\
\hline Winter muskmelon production & 195270.0 & 51820.0 & 108050. & 304570.0 & 24 \\
\hline Winter watermelon price & 476.01 & 83.97 & 339.50 & 760.30 & 24 \\
\hline Winter muskmelon price & 628.05 & 123.17. & 431.60 & 995.10 & 24 \\
\hline \multicolumn{6}{|c|}{ Texas } \\
\hline Spring onion production & 3226.9 & 608.5 & 1548.0 & 4800.0 & 35 \\
\hline Summer onion production & 1279.7 & 349.79 & 740.00 & 1881.0 & 35 \\
\hline Muskmelon production & 1902.0 & 673.33 & 724.0 & 3520.0 & 32 \\
\hline Honeydew production & 568.17 & 337.88 & 50.0 & 1240.0 & 35 \\
\hline Watermelon production & 5240.5 & 1158.6 & 3405.0 & 8800.0 & 32 \\
\hline Spring onion price & 14.69 & 6.36 & 7.22 & 37.16 & 35 \\
\hline Summer onion price & 14.31 & 4.59 & 8.03 & 31.97 & 35 \\
\hline Muskmelon price & 19.27 & 4.47 & 9.19 & 26.84 & 32 \\
\hline Honeydew price & 22.17 & 6.93 & 10.26 & 41.08 & 35 \\
\hline Watermelon price & 6.37 & 1.98 & 3.59 & 10.97 & 32 \\
\hline \multicolumn{6}{|c|}{ Florida } \\
\hline Fall squash & 353.50 & 137.17 & 128.94 & 625.8 & 27 \\
\hline Winter squash production & 398.94 & 156.39 & 156.24 & 770.7 & 27 \\
\hline Fall green pepper production & 791.34 & 495.82 & 218.12 & 2193.0 & 27 \\
\hline Winter green pepper production & 938.75 & 567.96 & 224.0 & 2385.9 & 27 \\
\hline Fall tomato production & 3590.1 & 1367.2 & 1092.0 & 5675.5 & 27 \\
\hline Winter tomato production & 3679.3 & 1671.4 & 1059.0 & 6814.3 & 27 \\
\hline Fall squash price & 25.41 & 5.91 & 14.25 & 37.12 & 27 \\
\hline Winter squash price & 24.65 & 7.62 & 8.07 & 41.68 & 27 \\
\hline Fall green pepper price & 29.92 & 10.01 & 16.45 & 63.47 & 27 \\
\hline Winter green pepper price & 37.07 & 19.24 & 17.11 & 97.03 & 27 \\
\hline Fall tomato price & 29.63 & 8.44 & 16.48 & 42.65 & 27 \\
\hline Winter tomato price & 32.93 & 7.85 & 18.55 & 46.14 & 27 \\
\hline \multicolumn{6}{|c|}{ California } \\
\hline Fall lettuce production & 9020.4 & 1414.1 & 6437.0 & 11359.0 & 25 \\
\hline Winter lettuce production & 7577.6 & 1852.6 & 3534.0 & 9652.0 & 25 \\
\hline Fall lettuce price & 17.26 & 4.77 & 10.16 & 30.93 & 25 \\
\hline Winter lettuce price & 11.11 & 3.55 & 5.15 & 19.49 & 25 \\
\hline \multicolumn{6}{|c|}{ Input variable } \\
\hline Wage rate in farm sector & 4.19 & 0.34 & 3.34 & 4.72 & 35 \\
\hline Wage rate in Mexico farm sector & 1.78 & 0.61 & 1.00 & 2.55 & 24 \\
\hline
\end{tabular}

${ }^{\mathrm{z}} \mathrm{U} . \mathrm{S}$. production is in thousands of hundredweights (cwt.) and prices are dollars/cwt. Mexico production is in metric tons, while prices are in pesos/metric ton. All prices are in real dollars or pesos.

The coefficients associated with the El Niño binary variables were negative in 11 equations and positive in six equations. Of the 11 negative coefficients, three were significant at the 0.20 or less level, whereas of the six positive coefficients, three were significant. The negative influence of El Niño events on supply was significant at the 0.10 level for Florida fall squash and significant for Texas muskmelon and California fall lettuce at the 0.15 and 0.20 levels. On average, El Niño events reduced Florida fall squash supply $\approx 21 \%$ relative to mean production during the study period (Table 3). Historically, the expected supply of Texas muskmelon was reduced $\approx 15 \%$ as a result of El Niño events, while expected California fall lettuce supply was reduced $\approx 5 \%$. In addition, El Niño events were found to have a positive, significant effect on U.S. summer onion, and Florida fall and winter tomato supplies. On average, El Niño events increased expected U.S. summer onion supply $\approx 7 \%$ and Florida fall and winter tomato supplies $\approx 10 \%$ and $25 \%$ relative to historic mean production.

Effects of La Niña events were also mixed.
For eight of the estimated equations, there was a negative relationshop between La Niña events and supply, while a positive association appeared in the remaining nine equations. Of the eight negative coefficients, three were significant at the 0.20 or less level, whereas, none of the positive coefficients were significant. Texas melon supplies (muskmelon, honeydew, and watermelon) were the only estimated equations with significant La Niña coefficients. La Niña events reduced expected Texas muskmelon, honeydew and watermelon production $\approx 20 \%, 29 \%$, and $13 \%$ relative to historic mean supplies (Table 3).

Discussion. The observed effects of $\mathrm{El}$ Niño and La Niña events on supplies of selected vegetables and melons were likely attributable to a variety of factors. Abnormal climate affected production because of its affect on plant growth, pollination, susceptibility to diseases and insects, maturation, density of fruit setting, and planting and harvesting activities. Most unfavorably affected by the abnormal climate was Texas melon production. El Niño events reduced production of all melons in Texas, however, only the $15 \%$ reduction in muskmelon production was statistically significant. In contrast, the La Niña events were found statistically significant in all Texas melon equations with production declining from $13 \%$ to $29 \%$. The cool conditions associated with an El Niño event may have unfavorably affected muskmelon yields, because of their sensitivity to low temperatures, especially when overnight temperatures decline to near $4.5^{\circ} \mathrm{C}$. Further, the wet conditions associated with an El Niño may encourage melon foliar diseases and fruit rot which also reduces yield and quality. Interestingly, the dry and warm conditions associated with La Niña events also had an unfavorable effect on Texas melon production. Texas watermelon was largely produced on nonirrigated acreage. Thus, the dry conditions associated with a $\mathrm{La}$ Niña may have reduced yields. During much of the study period, water disputes between New Mexico, Mexico, and Texas generated irrigation water shortages as did dry conditions in regions that fed reservoirs that provided water for south Texas vegetable and melon production. It follows that under the dry conditions of a La Niña, muskmelon and honeydew yields may have suffered because of an irrigation water shortage.

Florida tomato production was favorably affected by the El Niño events with fall and winter tomato production increasing $\approx 10 \%$ and $25 \%$ above their historical means when this event occurs (Table 3). Sittel indicated El Niño events tend to slightly increase Florida rainfall and have little effect on temperature during the October through December period, while in the January through March period, temperatures are lower than normal and rainfall is considerably above normal. There is no apparent explanation as to why these conditions may increase Florida fall and winter tomato production.

The cool and wet climate associated with El Niño events reduced expected California fall lettuce production $5 \%$ relative to mean historical production. It is hypothesized that cool nights with near freezing temperatures may generate leaf damage and a high respiration rate leading to rapid quality deterioration and declining yields. Similarly, expected Florida fall squash supply was reduced by $21 \%$ by El Niño events. The wet conditions associated with an El Niño event may hinder the daily harvests that were required to maintain squash quality and may also increase the occurrence of disease. Hence, reduced Florida fall squash yields during an El Niño event.

El Niño events had a negative influence on United States and Texas spring onion supply, but a statistically significant, positive impact on expected United States summer onion supply $(7 \%)$. The wet and cool conditions of El Niño events may have retarded spring onion growth, maturation, and harvest, leading to a decline in spring onion yield and production. Increased United States summer onion supply may have resulted, in part, from the reaction of producers to diminished spring onion production and the associated higher prices during El Niño events. Producers may have reacted to 
Table 2. Estimated supply equations (linear form) ${ }^{2}$ for various vegetable/melon crops in the United States and Mexico.

\begin{tabular}{|c|c|c|c|c|c|c|c|}
\hline Crop & Constant & $\begin{array}{c}\text { Lagged } \\
\text { production }\end{array}$ & $\begin{array}{c}\text { Lagged } \\
\text { price }\end{array}$ & $\begin{array}{l}\text { Wage } \\
\text { rate }\end{array}$ & El Niño & La Niña & $R^{2}$ \\
\hline \multicolumn{8}{|c|}{ United States } \\
\hline Spring onion & $\begin{array}{r}407.93 \\
(0.14)\end{array}$ & $\begin{array}{c}0.955 \\
(7.34)^{*}\end{array}$ & $\begin{array}{c}117.81 \\
(3.17)^{*}\end{array}$ & $\begin{array}{r}-345.05 \\
(-0.51)\end{array}$ & $\begin{array}{r}-217.49 \\
(-0.59)\end{array}$ & $\begin{array}{r}-340.30 \\
(-0.77)\end{array}$ & 0.63 \\
\hline Summer onion & $\begin{array}{c}732.61 \\
(0.51)\end{array}$ & $\begin{array}{c}0.780 \\
(7.34)^{*}\end{array}$ & $\begin{array}{l}58.535 \\
(2.72)^{*}\end{array}$ & $\begin{array}{c}-129.81 \\
(-0.39)\end{array}$ & $\begin{array}{l}253.92 \\
(1.38)^{* * * * *}\end{array}$ & $\begin{array}{c}147.61 \\
(0.65)\end{array}$ & 0.76 \\
\hline \multicolumn{8}{|c|}{ Mexico } \\
\hline Watermelon & $\begin{array}{l}29067 . \\
\quad(0.24)\end{array}$ & $\begin{array}{l}0.362 \\
(1.86)^{* *}\end{array}$ & $\begin{array}{l}246.72 \\
(1.69)^{* * * *}\end{array}$ & $\begin{array}{r}-13945 . \\
\quad(-0.53)\end{array}$ & $\begin{array}{r}13482.0 \\
(0.51)\end{array}$ & $\begin{array}{r}751.02 \\
(0.02)\end{array}$ & 0.38 \\
\hline Muskmelon & $\begin{array}{c}141360 . \\
(1.22)\end{array}$ & $\begin{array}{c}0.464 \\
(2.17)^{*}\end{array}$ & $\begin{array}{c}11.373 \\
(0.12)\end{array}$ & $\begin{array}{c}-19720 . \\
(-0.86)\end{array}$ & $\begin{array}{c}-10687 . \\
(-0.48)\end{array}$ & $\begin{array}{c}-22761 . \\
(-0.92)\end{array}$ & 0.38 \\
\hline \multicolumn{8}{|c|}{ Texas } \\
\hline Spring onion & $\begin{array}{c}1181.5 \\
(0.94)\end{array}$ & $\begin{array}{l}-0.025 \\
(-0.12)\end{array}$ & $\begin{array}{l}25.577 \\
(1.31)^{* * * * *}\end{array}$ & $\begin{array}{r}434.22 \\
(1.29)\end{array}$ & $\begin{array}{r}-271.51 \\
(-1.20)\end{array}$ & $\begin{array}{c}91.816 \\
(0.33)\end{array}$ & 0.10 \\
\hline Summer onion & $\begin{array}{c}-864.27 \\
(-1.65)^{*}\end{array}$ & $\begin{array}{c}0.404 \\
(2.90)^{*}\end{array}$ & $\begin{array}{l}32.227 \\
(3.62)^{*}\end{array}$ & $\begin{array}{c}281.79 \\
(2.01)^{*}\end{array}$ & $\begin{array}{c}-41.541 \\
(-0.45)\end{array}$ & $\begin{array}{r}-15.270 \\
(0.14)\end{array}$ & 0.57 \\
\hline Muskmelon & $\begin{array}{r}133.84 \\
(0.12)\end{array}$ & $\begin{array}{c}0.604 \\
(3.25)^{*}\end{array}$ & $\begin{array}{c}-15.034 \\
(-0.53)\end{array}$ & $\begin{array}{c}260.84 \\
(1.08)\end{array}$ & $\begin{array}{l}-289.50 \\
(-1.62)^{* * * *}\end{array}$ & $\begin{array}{c}-371.87 \\
(-1.53)^{* * * *}\end{array}$ & 0.57 \\
\hline Honeydew & $\begin{array}{r}-508.51 \\
(-0.99)\end{array}$ & $\begin{array}{c}0.844 \\
(5.74)^{*}\end{array}$ & $\begin{array}{l}9.976 \\
(1.34)^{* * *}\end{array}$ & $\begin{array}{c}99.434 \\
(0.88)\end{array}$ & $\begin{array}{c}-1.574 \\
(-0.02)\end{array}$ & $\begin{array}{c}-163.42 \\
(-1.52)^{* * * *}\end{array}$ & 0.60 \\
\hline Watermelon & $\begin{array}{r}891.10 \\
(0.40)\end{array}$ & $\begin{array}{c}0.790 \\
(3.61)^{*}\end{array}$ & $\begin{array}{c}129.88 \\
(1.07)\end{array}$ & $\begin{array}{c}-81.233 \\
(-0.13)\end{array}$ & $\begin{array}{r}-382.26 \\
(-0.91)\end{array}$ & $\begin{array}{l}-700.12 \\
(-1.37)^{* * * * *}\end{array}$ & 0.27 \\
\hline \multicolumn{8}{|c|}{ Florida } \\
\hline Squash fall & $\begin{array}{l}732.03 \\
(1.45)^{* * * * *}\end{array}$ & $\begin{array}{c}0.741 \\
(3.90)^{*}\end{array}$ & $\begin{array}{l}-1.770 \\
(-0.45)\end{array}$ & $\begin{array}{l}-131.54 \\
(-1.36)^{* * * * *}\end{array}$ & $\begin{array}{l}-74.279 \\
(-1.81)^{* *}\end{array}$ & $\begin{array}{c}0.340 \\
(0.01)\end{array}$ & 0.62 \\
\hline Squash winter & $\begin{array}{l}1126.2 \\
(1.83)^{* * *}\end{array}$ & $\begin{array}{c}0.589 \\
(2.98)^{*}\end{array}$ & $\begin{array}{l}-5.149 \\
(-1.24)\end{array}$ & $\begin{array}{l}-193.10 \\
(-1.57)^{* * *}\end{array}$ & $\begin{array}{c}-32.023 \\
(-0.59)\end{array}$ & $\begin{array}{c}57.962 \\
(0.85)\end{array}$ & 0.53 \\
\hline Green pepper fall & $\begin{array}{c}1552.4 \\
(1.03)\end{array}$ & $\begin{array}{c}0.801 \\
(4.68)^{*}\end{array}$ & $\begin{array}{c}2.188 \\
(0.25)\end{array}$ & $\begin{array}{r}-316.27 \\
(-0.90)\end{array}$ & $\begin{array}{l}101.97 \\
(-0.64)\end{array}$ & $\begin{array}{r}-108.99 \\
(-0.55)\end{array}$ & 0.55 \\
\hline Green pepper winter & $\begin{array}{r}734.66 \\
(0.44)\end{array}$ & $\begin{array}{c}0.872 \\
(5.31)^{*}\end{array}$ & $\begin{array}{c}4.441 \\
(0.95)\end{array}$ & $\begin{array}{r}-184.85 \\
(-0.49)\end{array}$ & $\begin{array}{r}-101.71 \\
(0.58)\end{array}$ & $\begin{array}{c}74.29 \\
(0.37)\end{array}$ & 0.57 \\
\hline Tomato fall & $\begin{array}{c}1220.4 \\
(0.50)\end{array}$ & $\begin{array}{c}0.844 \\
(8.67)^{*}\end{array}$ & $\begin{array}{l}-3.058 \\
(-0.18)\end{array}$ & $\begin{array}{r}-143.16 \\
(-0.26)\end{array}$ & $\begin{array}{l}366.31 \\
(1.56)^{* * * *}\end{array}$ & $\begin{array}{c}19.096 \\
(0.07)\end{array}$ & 0.88 \\
\hline Tomato winter & $\begin{array}{c}4335.6 \\
(0.71)\end{array}$ & $\begin{array}{c}0.600 \\
(3.33)^{*}\end{array}$ & $\begin{array}{l}-1.700 \\
(-0.04)\end{array}$ & $\begin{array}{c}-736.2 \\
(-0.52)\end{array}$ & $\begin{array}{l}918.14 \\
(1.59)^{* * * *}\end{array}$ & $\begin{array}{c}600.13 \\
(0.89)\end{array}$ & 0.44 \\
\hline Lettuce fall & $\begin{array}{c}-468.55 \\
(-0.10)\end{array}$ & $\begin{array}{c}0.861 \\
(7.07)^{*}\end{array}$ & $\begin{array}{c}\text { Califo } \\
52.186 \\
(1.64)^{* * * * *}\end{array}$ & $\begin{array}{r}230.67 \\
(0.27)\end{array}$ & $\begin{array}{l}-471.17 \\
(-1.39)^{* * * * *}\end{array}$ & $\begin{array}{r}275.28 \\
(0.60)\end{array}$ & 0.74 \\
\hline Lettuce winter & $\begin{array}{l}-4441.8 \\
\quad(-1.62)^{* * * *}\end{array}$ & $\begin{array}{c}0.993 \\
(12.98)^{*}\end{array}$ & $\begin{array}{c}42.448 \\
(1.08)\end{array}$ & $\begin{array}{l}896.78 \\
(1.42)^{* * * *}\end{array}$ & $\begin{array}{r}102.02 \\
(0.34)\end{array}$ & $\begin{array}{c}10.099 \\
(0.03)\end{array}$ & 0.89 \\
\hline
\end{tabular}

${ }^{\mathrm{z}} t$ ratios in parenthesis.

${ }^{*}, * *, * * *, * * * *$ Significant at the $0.05,0.10,0.15$, and 0.20 levels, respectively

the higher spring onion price by expanding acreage planted to short-season summer onions in the spring period, thus increasing summer onion production during El Niño events.

Over the last three decades, the production of selected United States vegetable and melon crops experienced mixed effects from the evaluated climate anomalies. In the case of El Niño events, expected declines in supply ranged from $5 \%$ of historic mean production for California fall lettuce to $21 \%$ for Florida fall squash. Expected positive production responses were highest for Florida winter tomatoes whose output increased $25 \%$ above the historic mean during an El Niño event. For La Niña events, expected production shortfalls range from $13 \%$ of historic mean production for Texas watermelon to $\approx 29 \%$ for Texas honeydew melons. In no estimated supply equation did the La Niña event have a statistically significant and positive effect on production.

El Niño and La Niña events created a comparative disadvantage for Texas melon production. Production shortfalls due to extended exposure to adverse weather in Texas have resulted in important reductions in melon planted area and production. Abnormally high rainfall and cool climate (El Niño) in Texas reduced muskmelon production, while drier than normal conditions (La Niña) lowered muskmelon, honeydew and watermelon production. When Texas melon crops are late in maturing, they compete with expanded production from other United States regions and the associated lower market prices. Further, many other melon production regions can respond to adverse conditions in Texas because of their later planting dates. Reliable predictions regarding future seasonal climate events may offer an important guide to planting and production of vegetables and melons.

Better understanding of the interaction between climate and production is essential for improved risk identification and more effective management. Knowing which crops to plant and when, along with the influence of expected climate patterns, are important elements of farm profitability and risk management. More reliable long-term seasonal climate forecasts, coupled with some measure of the expected magnitude of the effect of climate on production, may provide benefits to the U.S. vegetable and melon sectors.
Some caveats regarding the results of this study should be offered. Given the nature of agriculture production data, only one observation was obtained per season per year. This limited the number of observations on the different ENSO events. Other methods of defining ENSO events should be investigated, including categorizations of El Niño, and $\mathrm{La}$ Niña by season. Examining other climatological phenomenon, such as the North Atlantic Oscillation and Pacific North American QuasiBiennial Oscillation, may be fruitful given emerging knowledge on the relationship of these phenomenon and climate events (Mjelde, Hill, and Griffiths). As with any economic time series data, technological change may be a factor. Supply was estimated directly instead of by separate yield and acreage equations. Separate equations for yield and acreage would allow an analysis into the effects of ENSO events on yields and acreage planted/harvested. To determine welfare impacts, the supply equations must be used in conjunction with demand. Finally, and most important, the mixed results on the effect of ENSO events on vegetable and melon supply suggest more detailed analyses are necessary. Analyses based 
Table 3. Estimated statistically significant ( 0.20 or less level) expected effects of El Niño /La Niña events on vegetable/melon supply.

\begin{tabular}{|c|c|c|c|}
\hline Crop & $\begin{array}{l}\text { \% Change } \\
\text { in supply }{ }^{z} \\
\end{array}$ & $\begin{array}{c}\text { Period } \\
\text { planted/harvested }\end{array}$ & $\begin{array}{c}\text { Expected seasonal } \\
\text { climate effect }^{y}\end{array}$ \\
\hline \multicolumn{4}{|c|}{ El Niño effects } \\
\hline $\begin{array}{l}\text { U.S. summer onions } \\
\text { (New Mexico, Texas, Washington, } \\
\text { major producing states) }\end{array}$ & 7 & $\begin{array}{l}\text { Plant: Oct.-Mar. } \\
\text { Harvest: June-Aug. }\end{array}$ & $\begin{array}{l}\text { TX: wet/cool } \\
\text { NM: wet/cool } \\
\text { WA: dry/warm }\end{array}$ \\
\hline Texas muskmelon & -15 & $\begin{array}{l}\text { Plant: Jan.-Apr. } \\
\text { Harvest: May-Sept. }\end{array}$ & Wet/cool \\
\hline Florida fall squash & -21 & $\begin{array}{l}\text { Plant: July-Sept. } \\
\text { Harvest: Oct.-Dec. }\end{array}$ & Wet/cool \\
\hline Florida fall tomato & 10 & $\begin{array}{l}\text { Plant: July-Sept. } \\
\text { Harvest: Oct.-Dec. }\end{array}$ & Wet/cool \\
\hline Florida winter tomato & 25 & $\begin{array}{l}\text { Plant: Oct.-Nov. } \\
\text { Harvest: Jan.-Mar. }\end{array}$ & Wet/cool \\
\hline California fall lettuce & -5 & $\begin{array}{l}\text { Plant: July-Oct. } \\
\text { Harvest: Oct. - Dec. }\end{array}$ & Wet/cool \\
\hline \multirow[b]{2}{*}{ Texas muskmelon } & La Niñ & & \\
\hline & -20 & $\begin{array}{l}\text { Plant: Jan.-Apr. } \\
\text { Harvest: May-Sept. }\end{array}$ & Dry/warm \\
\hline Texas honeydew & -29 & Plant: Jan.-Apr. & \\
\hline \multirow[t]{2}{*}{ Texas watermelon } & -13 & $\begin{array}{l}\text { Harvest: May-Sept. } \\
\text { Plant: Jan.-Apr. }\end{array}$ & Dry/warm \\
\hline & & Harvest: May-Sept. & Dry/warm \\
\hline
\end{tabular}

${ }^{2}$ Percentage of change from the historical mean.

${ }^{y}$ Composite effects from (Hammer et al., 1996; National Oceanic and Atmospheric Administration, 1998; Ropelewski and Halpert, 1986, 1987, 1989; Green 1997).

on smaller regions and possibly shorter seasons may help determine localized effects of ENSO events. Further, such analyses may provide insight into how the plant responses biophysically to conditions (climate, insects, disease, etc.) associated with ENSO events.

\section{Literature Cited}

Banco de Mexico. 1970-1994. Subdirección de investigación económica. Indicadores económicos. Mexico, D.F., various issues, 1970-94.

Banerjee, A.N. and J.R. Magnus. 2000. On the sensitivity of the usual $\mathrm{t}$ - and F-tests to covariance mispecification. J. Econometrics 95:157-176.

Cane, M.A., G. Eshel, and R.W. Buckland. 1994. Forecasting Zimbabwean maize using eastern equatorial Pacific sea surface temperature. Nature 370:204-205.

Comisión Nacional de los Salaries Mínimos. 1997. Fax correspondence, Mexico, D.F.

Florida Department of Agriculture and Consumer Service. 1969-96. Florida agricultural statistics, vegetable summary, Orlando, various issues.
Glantz, M. 1996. Currents of change. Cambridge Univ. Press. Cambridge, Great Britain.

Green, P.M., D.M. Legler, C.J. Miranda, and J.J. O'Brien. 1997. The North American climate patterns associated with the El Niño-Southern oscillation. Center for Ocean-Atmospheric Prediction Studies. The Florida State Univ., Tallahassee. COAPS Project Rpt. Ser. 97-1.

Gujarati, D.N. 1995. Basic econometrics. McGrawHill, New York.

Hammer, G., R. Stone, and T. Marcussen. 1996 Prediction of global rainfall probabilities using phrases of the southern oscillation index. Nature 384:252-255.

Kiladis, G.N. and H.F. Diaz. 1989. Global climatic anomalies associated with extremes of the Southern Oscillation. J. Climate 2:1069-1090.

Mjelde, J.W., H.S.J. Hill, and J.F. Griffiths. 1998. A review of current evidence on climate forecasts and their economic effects in agriculture. Amer. J. Agr. Econ. 80:1089-1095.

Mjelde, J.W. and K. Keplinger. 1998. Using the southern oscillation to forecast Texas winter wheat and sorghum crop yields. J. Climate 11:5460 .
National Oceanic and Atmospheric Administration. 1998. Web pages. Accessed Dec. 1998. http:// www.nnic.noaa.gov:80/products/analysis_ monitoring/ensostuff/dist/netdist.html and http:/ /www.nnic.noaa.gov/products/analysis monitoring/ensostuff/lanina/index.html.

National Oceanic and Atmospheric Administration. 2001. Web page. Accessed Apr. 2001. http:// www.nnic.noaa.gov:80/products/analysis_ monitoring/ensostuff/ensoyears_1877present.html.

Nicholls, N. 1988. Use of the Southern Oscillation to predict Australian sorghum yield. Agr. and For. Meteorol. 38:9-15.

Ropelewski, C.F. and M.S. Halpert. 1986. North American precipitation and temperature patterns associated with the El Niño/Southern Oscillation (ENSO). Monthly Weather Rev. 114:2352-2362.

Ropelewski, C.F. and M.S. Halpert. 1987. Global and regional scale precipitation and temperature patterns associated with the El Niño/Southern Oscillation. Monthly Weather Rev. 115:16061626.

Ropelewski, C.F. and M.S. Halpert. 1989. Precipitation patterns associated with the high index phase of the Southern Oscillation. J. Climate 2:268-284.

Secretaría de Agricultura y Recursos Hidraulicos. 1970-94. Subsecretaría de planeación. Anuarios estadísticos de la producción agrícola de Los Estados Unidos Mexicanos. Mexico, D.F., various issues.

Sittel, M.C. 1994. Differences in the means of ENSO extremes for maximum temperature and precipitation in the United States. Center for OceanAtmospheric Prediction Studies. The Florida State Univ., Tallahassee,. Tech. Rpt. 94-2.

Texas Department of Agriculture. 1961-96. Texas Agr. Stat. Serv., Texas Veg. Stat., Austin, various issues.

Tomek, W.G. and K.L. Robinson. 1981. Agricultural product prices. Cornell Univ. Press, Ithaca, N.Y.

U.S. Department of Agriculture. 1971-96. Fresh fruit and vegetable shipments by commodities, states, and months. Washington, D.C., various issues.

U.S. Department of Agriculture. 1961-96. Agr. prices. Washington, D.C., various issues.

U.S. Department of Agriculture. 1961-96. Agr. stat. Washington, D.C., various issues.

U.S. Government Printing Office. 1996. Economic report of the President. Washington, D.C.

Wyrtki, K.E., W. Patzert, R. Williams, and W. Quinn. 1976. Predicting and observing El Niño. Science 191:343-346. 